\title{
Downregulating oncogenic receptor: From bench to clinic
}

\author{
George Zhu' ${ }^{*}$, Ali-Akmbar Saboor-Yaraghi' ${ }^{2}$ Yosef Yarden ${ }^{3}$ Joana Santos $^{4}$ and Neil JC ${ }^{5}$ \\ ${ }^{1}$ Institute of Oncology of George Zhu, 422407, Beijing, China \\ ${ }^{2}$ Department of Cellular and Molecular Nutrition, School of Nutritional Sciences and Dietetics, Tehran University of Medical Sciences, Tehran, Iran \\ ${ }^{3}$ Department of clinical Immunology, Weizmann Institute of Science, Rehovot 76100, Israel \\ ${ }^{4}$ Department of Genetics and cancer Genetics Group-CI-IPOP, Portuguese Oncology Institute Porto, Portugal \\ ${ }^{5}$ Beatson Institute for Cancer Research, Switchback Road, Bearsen, Glasgow G61 IBD, UK
}

\begin{abstract}
In 1989-1991, George Zhu first postulate oncogenic receptor (Voice of America,1992,12:31;Curr Pharm Biotechnol,2013,14:859-863), as a result of his experiments in which steroid PML-RARa fusion receptor gene rearrangement within it(15;17) translocation in acute promyelocytic leukemia (APL), FGFR-1) receptor induced tumours of the breast glands in two aplastic anemia during the course of testosterone treatment (hormonal tumorigenesis). In the past 2-3 decades, there are at least 30 receptor genes involving in various of oncogenic process. These normal physiologic receptors linked to gene amplification, rearrangement, deletion and activating mutations, which converted receptor to oncogenic (also oncogenic receptor) in development, progressive and pathogenesis of benign and malignant diseases. Receptors included nuclear receptor family members (oncogenic estrogen/estrogen receptor alpha signaling, oncogenic androgen receptor, oncogenic receptor pml/RARa, and GR $\beta$ ); Oncogenic growth factor receptors (EGF/oncogenic receptor EGFR, Neu oncogenic receptor, insulin receptor substrate 4 IRS4/insulin receptor/c-ros protooncogenic receptor, insulin and IGF-1 and -II/oncogenic IGF-1R, oncogenic PDGFAR, oncogenic TEL/PDGFRB, HGF/HGFR、 met oncogenic receptor); Cytokine receptor rc family members (IL-2-BCM fusion,IL-3/oncogenic IL-3Ra,IL-7/oncogenic IL-7R and IL-21R-BCL6 fusion); Cytokine receptors including the $\beta c$ family (G-CSF/oncogenic CSF3R,oncogenic EPOR), and oncogenic autocrine growth hormone/nuclear GHR and other VEGFR2. Upon ligand binding or external antigen stimuli, mutated growth factor receptors and mutant cytokine receptors including type I cytokine receptor may be activated via ligand binding receptor complex, receptor dimerizes especially receptor homodimerization, and induces transphosphorylation of tyrosine residues in the cytoplasmic domains which serves as docking sites for several adaptor molecular harboring SH2 domain or phosphotyrosine binding domain. These adaptor molecules recruit and activate downstream signaling molecules such as Ras/MAPK, phospholipase C-r,JAK-STAT molecules, NF-KB pathways through tyrosine- or serine/threnonine-phosphorylation. Among them, Ras /MAPK/ERK, PI3-K/akt and STAT pathways act as the major oncogenic signaling pathway. Overall, these receptors coupled with their ligands are key importance in human subtle balance in physically regulating multiple cellular processes, for example, in cellular proliferation and differentiation. Oncogenic receptors mutational activation and/or aberrant gene rearrangement are promiscuously interference with normal cell survival, anti-apoptosis and proliferation, and malignant initiation and progression. Others, in a special APL case, oncogenic pml/RARa fusion behave as a potent (constitutive) transcriptional repressor of RAR and retinoic acid signaling, inducing a differentiation blockage at promyelocytic stage which can be overcome with therapeutic doses of 9-cis retinoic acid or ATRA ligand (see in detail model, George Zhu, January 1991. Curr Pharm Biotechnol, 2013, 14: 849-8E). This is the classical model of retinoic acid action. This encourage receptor normal agonist, and oncogenic receptor antagonists (or inhibitors) target therapy.
\end{abstract}

\section{Introduction}

Since introduction of oncogenic receptor concept by George Zhu from oncogenic pml/RARa fusion in etiology of a specific APL and androgen/androgen receptor oncogenic signaling in role of hormonal tumorigenesis in early 1989s [1-7], de The $\mathrm{H}$ and Chomienne C $[8,9]$, at the same peroid, found that in $\mathrm{t}(15 ; 17)$ APL the translocated retinoic acid receptor alpha (an RAR mutant) contribute to leukemogenesis. Neil JC [10] is in detail receptor-mediated leukaemogenesis from the oncogenic function of $\mathrm{T}$ cell antigen receptor (TCR oncogenic signal) on lymphoid cells not only bind external ligand but are crucial in cellular proliferation. In transgenic mice expressing a mutated TCRbeta lacking the variable chain (Detta V-TCRbeta) developed CD+, CD8+, IL-2Ra positive T-cell lymphoma [11]. Patients with ataxia-telanglectasia are particularly prone to development of T-cell chronic lymphocytic leukemia with chromosomal abnormalities. The breakpoint is composed of a TCR J alpha chain region (from 14q11) fused to sequences derived from $14 \mathrm{q} 32$ but on the centromeric side of the $\operatorname{IgCmu}(\operatorname{IgH})$, indicating that a $14: 14$ translocation $[\mathrm{t}(14 ; 14)$ (q11;q32); inv(14)(q11;q32)] in the development of T-cell tumors [1213]. Like mutated oncogenic growth factor receptors [14], antigen- independent $\mathrm{B}$ cell receptor (BCR) signaling drives the oncogenic process. The genetic defects in heavy-chain disease(HCD) result in the production of abnormal membrane-associated heavy chain lacking an antigen-binding domain, these aberrant B-cell antigen receptors might engage in ligand-independent signaling, indicating a role in the genesis of HCD neoplasia [14-15].

Yarden Y [16] proposes neu oncogenic receptor from neu oncogenerelated receptor tyrosine kinase (RTK), and this might be useful in neu oncogenic receptor [17-21] antagonists lapatinib and trastuzumab target therapy in metastatic breast cancer with HER2V659E mutation [22]. In a large trials of 48 HER2-positive early breast cancer patients, the adjuvant trastuzumab treatment demonstrates highly favorable

Correspondence to: George Zhu, Institute of Oncology of George Zhu, 422407, Beijing, China, E-mail: sansan4240732@163.com

Key words: receptor; oncogenic receptor; gene mutation; rearrangement tumours/cancers

Received: September 22, 2016; Accepted: October 13, 2016; Published: October 16,2016 
outcome. Five-year overall survival rates and disease free survival rates were $95.8 \%$ and $93.8 \%$ respectively. Al-Nedawi [23] explore the area that microvesicles containing oncogenic receptor EGFRVIII released to cellular surroundings and blood of tumour-bearing mice, and can merge with the plasma membranes of cancer cells lacking EGFRVIII. This intercellular transfer of membrane-derived microvesicles ('oncosomes'-small plasma membrane buds, Robinson, [24]) leads to the transfer of oncogenic activity including activation of MAPK and Akt and autocrine activation of its key signaling receptor (VEGF receptor-2), and increases in anchorage-independent growth capacity. Santos [25] studies oncogenic GRPR (gastrin-releasing peptide receptor) in neoplastic multiple signaling pathway. Somatic mutations in cholecystokinin 2 receptor(CCK2R) alter receptor activity that promote oncogenic phenotype, and the importance of evaluating CCK2R inhibitors to block mutant forms of this receptor [26]. Intriguing, epithelial cell adhesion molecule (EpCAM), as a homophilic adhesion protein, is a novel oncogenic receptor which frequently overexpressed in epithelia, progenitors, embryonic stem cells, carcinoma and cancer-initiating cells, and target its antibodies [27]. The present will in brief focus on recent innovative diagnostic and therapeutic strategies forthcoming in this area.

\section{Steroid hormone receptors oncogenic signaling}

The estrogen receptor(ER) is found in a wide variety of species and is involved in the programming and regulation of gene expression in vertebrate female sex-accessory tissue [28]. Estrogen E2/ERa signaling plays an important role in the regulation of mammary gland development and function, and also contributes to the onset and progression of breast cancer. More than $70 \%$ of human breast cancers express ERa, and elevated levels of ERa in benign breast epithelium correlate with increased risk of breast cancer [29]. Green S and Chambon P [28] described oncogenic hormone receptor from human oestrogen receptor cDNA sequence. This carcinogenicity of estrogen is attribute to receptor-mediated stimulation of cellular proliferation. Increased proliferation could result in turn in accumulation of genetic damage and stimulation of the synthesis of growth factors that act on the mammary epithelial cells via an autocrine or paracrine loop [30]. There were evidence that estrogen-dependent cell line(MCF-7) cells under estradiol(E2) stimulation release some known polypeptide growth factor activities (EGF-like, IGF-1-like) [31]. Dickson RB and Stancel GM [32] discuss estrogen receptor-mediated processes in normal and cancer cells. ER-mediated regulation of gene expression plays many significant roles in normal and cancer cells and this will improve the understanding of hormonal carcinogenesis.

Furthermore, Russo [33], Santen, et al. [34], Yager and Yue [35] discussed estrogen receptor-dependent and independent mechanisms of breast carcinogenesis. ERa mediated stimulation of breast cell proliferation with a concomitant enhanced rate of mutations, and estradiol metabolites to genotoxic DNA mutation cause DNA damage. Thus, ERa function as estrogen activated transcription factor and involved in the stimulation of estrogen target genes in the regulation of cell cycle progression and growth of breast epithelium [36]. As Clarke described [37], some ERa/PR-positive epithelial cells are quiescent breast stem cells that acts as 'steroid hormone sensors'. Such hormone sensor cells are likely to secrete positive or negative paracrine/juxtacrine factors dependent on the prevailing estrogen or progesterone concentration to influence the proliferative activity of adjacent ERa/PR- epithelial cells. This might represent one step toward the development of neoplasia and malignancy-invasive tumors.
Utilizing ERKO/wnt-1 oncogene mice [38] and aromatase/ERKO transgene mice [39], they demonstrated the role of ERa-dependent in mammary development and carcinogenesis. Lack of ERa mice results in impaired mammary development and much delayed tumor incidence even in the presence of tissue estrogen (50\% of mammary tumors at 5 months in ER-positive animals versus 11 months in those without $\mathrm{ERa})$. Whereas introduction ERa into the tTA/TAg mice [40] and DES-treated MT-mER transgene mice [41,42] developed mammary adenocarcinoma (at 8months) and preneoplastic lesion atypical hyperplasia (at 4 months), which implicate that ERa contributes to carcinogenic through ER-mediated signal transduction, increasing estrogen-responsive cell proliferation, and ERa signaling in mammary cancer initiation and progression.

Moreover, mutations in estrogen receptor converted estrogen receptor-dependent breast tumor into estrogen-independent growth [43]. Fuqua [44] found a K303R estrogen receptor alpha (ERa) mutation in human premalignant breast lesions. The K303R mutation formed tumors in nude mice faster than cells expressing wild-type ERa in the presence of low levels of estrogen (at 10-12 M estradiol), and those K303R ERa-expressing tumors are estrogen-independent growth [45]. From screeing of those ER+ breast cancer, Veeraraghavaa and colleagues [46,47] detected oncogenic ESR1- CCDC170 fusion positive tumors. This neoplastic ESR1-CCDC170 fusion leads to anchorageindependent growth, reduced endocrine sensitivity and enhanced xenograft tumor formation, suggesting a new concept of this oncogenic receptor ESR1 fusion in pathobiology in a more aggressive subtype of breast cancer.

Thus far, in addition to tamoxifen and fulvestrant, AZD9496, a nonsteroid small molecule inhibitor of oncogenic (or neoplastic, due to not targeting normal ERa) Era $[2,29,40,41,48]$, bound and down-regulated clinically relevant ESR1 mutants in vitro and inhibited tumor growth in an ESR1 mutant patient-derived xenograft model that included a Y537 and D538G mutation [49,50]. AZD9496 is currently being evaluated in a phase I clinical trial [50].

Using heterotypic tissue recombination, Cunha [51] established a stromal androgen receptor for mesenchymalepithelial transition(EMT) in normal androgen-dependent prostate development and in the etiology of benign prostatic hyperplasia [52]. By different methods including immortalized human prostate cells expressing androgen receptor [53] and androgen receptor transgene [54], they demonstrated that androgen receptor is oncogenic, and this oncogenic receptor induces prostate intraepithelial neoplasia(PIN) and plays a crucial role in transforming process in prostate cells. The ARexpressing PrECs are dependent on circulating testosterone for tumor growth, and immortalized PrECs lacking AR failed to form tumors. But this androgen receptor is difficult to characterize as an oncogene [53]. Mononen [55] and Koivisto [56] detected the R726L mutation of androgen receptor (AR) in Finnish patients with sporadic or familial prostate cancer, which may confer an up to 6-fold increased risk of a small fraction of prostate cancer in Finlan. T877A mutation of AR was identified in LNCaP cell line and metastatic cells of androghenindependent prostate cancer [57-63], whereas V739M was identified in early stage PCa [64]. Nyquist [65] discovered intragenic AR gene rearrangements in CRPC tissues, rendering expression of truncated AR variants proteins lacking the AR ligand-binding domain, constitutive activity of AR, and intragenic ARv567es cDNA formed tumor faster rate and a CRPC growth independent of full-length AR or androgens. Therefore, targeting oncogenic AR variants $[3,53,66-70]$ (here, please note that it is no need to target a normal AR) includes AR antagonists 
bicalutamide and enzalutamide, which might provide an approach to suppress prostatic intraepithelial neoplasia(PIN) development. In phase II trials, the CBR (clinical benefit rate) of $19 \%$ was observed with bicalutamide $150 \mathrm{mg}$ daily dose in selected patients with androgen receptor-positive, estrogen receptor-negative metastatic breast cancer [71].

In another area, increased thyroid diseases and thyroid papillary carcinoma (PTC) associated with a high dietary iodine intake [3,72-81].

GR $\beta /$ STAT-5 pathway was found to be involved in erythrocytosis [82], and GR/SGK1 (including GR-SGK1-FOXO3a signaling pathway and GR-SGK1-MKP1/DUSP1 pathway) network linked to higher tumor grade and antiapoptotic and increased cancer recurrence [83-85]. Moreover,the aberrant glucocorticoid receptor signaling in breast cancer [86-89], prostate hyperproliferation [85,90,91], Cushing's disease [92] and Nelson's syndrome [93]. Thus, GR activation is sufficient to provide a potent signal for cell survival in mammary epithelial cells. Induction of serum and glucocorticoidregulated kinase-1 (SGK-1) expression is required for GR-mediated epithelial cell survival signaling. SGK-1 is a direct GR target and encodes a serine-threonine kinase with significant homology to Akt1. In immunohistochemical analysis, nucleus GR-immunostaining and glucocorticoid receptor (GR)- immunopositive cells were abundantly present in subclinical Cushing's disease due to pituitary adenomas (2 macroadenomas and 8 microadenomas), suggesting impaired glucocorticoid action, at least in part, in tumorigenesis of this disease [92]. RU486(mifepristone), a glucocorticoid receptor antagonist, has been successful treatment of the Cushingoid phenotype with markedly elevated lymphocyte glucocorticoid receptor numbers in a transient Cushing's syndrome [94]. Mifepristone may also be a useful strategy for increasing tumor cell apoptosis in chemotherapy-resistant GR+ triple- negative breast cancer(TNBC) [95]. In addition, the cortisol/ cortisone-responsive AR (AR(ccr)) has two mutations ( $\mathrm{L701H}$ and T877A) that were detected in the MDA PCa human prostate cancer cell lines established from a castrated patient whose metastatic tumor exhibited androgen-independent growth. GR antagonist RU38486 showed inhibitory activity [90], but its therapeutic application to treat prostate cancer may be limited. Thus, the combination of ARccr receptor antagonists bicalutamide (casodex) together with a ligand suppressor(triamcinolone) represents a new therapeutic strategy for the treatment of the subset of androgen-independent prostate cancers harboring the $\mathrm{L} 701 \mathrm{H}$ or ARccr type.

So far, there is a conflict among hormone FSH/FSH receptor in etiology of epithelial ovarian cancer [96,97]. Actions of FSH (folliclestimulating hormone) in reproductive physiology are essential for folliculogenesis and steroidogenesis [98], FSH receptor (FSHR), a transmembrane receptor with a $G$ protein-coupled signaling, is expressed by granulosa cells in developing ovarian follicles. Overexpression of FSHR activates oncogenic pathways through FSHRinduced EGFR amplification, and HER-2/neu and activated ERK1/2 in preneoplastic immortalized ovarian surface epithelial(IOSE) cells [99]. The data by epidemiological studies that an increased occurrence of ovarian cancer has been suggested with exposure to high levels of gonadotropins during postmenopause or infertility therapy [100-102].

Retinoids can regulate proliferation and differentiation of normal myeloid cells, and that supraphysiological levels of retinoic acid (9cis RA or all-trans RA) can induce abnormal promyelocytes toward maturation. These leukemic cells harboring steroid PML-RARA translocation play a central role in etiology of APL $[4,8,9,103]$. The
PML-RARa chimera can function as a strong transcriptional repressor of retinoic acid (RA) signaling and RAR function by pertubing normal retinoid signaling, leading to a block in differentiation and in an accumulation of leukemic cells at promyelocytic stage [4,6,103-115]. This oncogenic receptor is locked in its "off" regulated mode thereby constitutively repressing transcription of genes or key enzymes that are critical for differentiation of hematopoietic cells [4,116]. Moreover,the PML-RARa apparently involved in part the defects in ability to release corepressor under physiological hormone concentration. The wild-type RARa readily form heterodimer with the retinoid $\mathrm{X}$ receptors(RXRs). In contrast, chimeric pml/RARa oncoprotein exhibited an enhanced ability to bind to DNA as homodimer. This enhanced homodimerization by RAR chimeras implicates in aberrant corepressor interaction properties of these oncogenic receptor derivatives, influences their DNA recognization, and appears to prevail in neoplastic cells of these oncoproteins [103]. These differences in target gene recognition by the normal and oncogenic RARa protein may contribute to the leukemogenic phenotype [103].

\section{Targeting oncogenic growth factor receptors}

The EGF receptor(EGFR) [117] has a key role in normal embryonic development, adult tissue hemeostasis and many pathological processes, particular tumor formation. Aberrant EGFR activation becomes oncogenic due to overexpression and/or amplification of the EGFR gene or by autocrine/paracrine growth factor loops, whereas activating dimerized mutations promote EGFR signaling, which lead to ligand-independent $[118,119]$. Phosphorylation of this oncogenic receptor at residues Tyr845, Tyr1045 and Tyr1173 leads to receptor activation and downstream signaling [120,121]. Oncogenic receptor EGFR $[2,5,7,119,122-124]$ was found to involved in A431 human carcinoma cells [125-128], squamous cell carcinoma (SSC) [129], epithelial cell lines from mammary carcinoma [130], glioblastoma stem cells [5,131,132,EGFR+++ positive in one glioma, George Zhu], and colorectal carcinoma tissue[133]. Oncogenic EGFR mutations are found in $10 \%$ to $35 \%$ of lung adenocarcinomas, with predominant in a subset of patients with non-small cell lung cancer (NSCLC) [134136]. These mutations, which commonly occur as either small inframe deletions in exon19 or point mutations T790M and L858R in exon21 within the EGFR tyrosine kinase domain, confer constitutive activity and sensitivity to EGFR tyrosine kinase inhibitors(TKI) [137,138]. Recent, Gallant [137] identified a novel EGFR alteration in lung cancer: EGFR exon18-25 kinase domain duplication(EGFRKDD). EGFR-KDD is oncogenic and oncogenic EGFR-KDDtransformed cells are sensitive to the EGFR TKI afatinib. Konduri and colleagues [138] reported five patients with metastatic lung cancer whose tumors harbored EGFR fusion, most commonly RAD51, are recurrent in lung cancer. Four of whom were treated with EGFR TKI erlotinib with documented antitumor response for 5,6,8, and 20 months respectively. These patients whose tumors harbored EGFR fusions are oncogenic in preclinal studies. In mouse model, transgenic mice expressing EGFR L858R in type II pneumocytes developed atypical adenomatous hyperplasia and multifocal adenocarcinoma, and gefitinib inhibited tumorigenesis completely [139]. Blesa [140] present a durable complete remission of a relapsed glioblastoma with a complete radiologic response and the combination of cetuximab and bevacizumab in a third-line setting, that has offered a progression-free survival of 20 months. In Cuba, CimaVax-EGF, promising, an active vaccine targeting EGF as the major ligand of EGFR, it is in use as a cancer therapy against non-small-cell lung cancer (NSCLC) [141,142]. 
PDGFRa mutations are oncogenic(tumorigenic) and developed $100 \%$ of mice with brain tumors whereas only one of 19 mice implanted with cells overexpressing wild-type PDGFRa developed into brain tumor in vivo [143]. This D842V mutant was effectively inhibited by crenolanib, a specific inhibitor of PDGFRa and PDGFR $\beta$. Golub [144] identified that PDGF receptor $\beta$ is oncogenic in pathogenesis of chronic myelomonocytic leukemia with $t(5 ; 12)$ chromosomal translocation, targetable oncogenic receptor tyrosine kinases PDGFRa/ PDGFR $\beta$, and FGFR fusions [145-147] in diverse cancers have made some major progress. For example, these hypereosinophilia (HES) patients with FIP1L1/PDGFRA have excellent responses to imatinib treatment [148-153]. At present, Imatinib, a selective inhibitor of ABL, KIT, and PDGFRA/B, is the first line target therapy for gastrointestinal stromal tumor (GIST) [154].

Hepatocyte growth factor (HGF), like other growth factors, has different effect in different cells. HGF regulates cell growth, cell mortality and morphogenesis by acting a tyrosine signaling cascade after binding to the proto-oncogenic receptor for HGF (HGFR, also proto-oncogenic receptor c-met, met receptor) [155-158]. HGF enhances hepatocyte growth, potently suppresses apoptic death of hepatocytes and decreases serum bilirubin and serum ALT (alanine aminotransferase), which provide therapeutic action of HGF, including severe hepatitis, falminant hepatic failure [159] and liver cirrhosis [160].

HGF-HGF receptor (met oncogenic receptor) signaling stimulate growth of mouse C127 cells transformed phenotype [161], Caki-1 (a human kidney clear cell carcinoma cell line), U87-MG (a glioblastoma cell line) [162], canine osteosarcoma cells [157], and human hepatoblastoma cells [163], and AML [164].

In vitro HGF can transform immortalized mouse liver epithelial cells [165]. Serum HGF levels are elevated in patients suffering from chronic hepatitis and liver cirrhosis. Moreover, hepatocytes from transgenic mice expressing HGF grew more rapidly than did those from normal siblings. In vivo, Fao HGF cells produced tumors when transplanted into nude mice [166]. These conditions cause persistent hepatocellular damage and regeneration; consequently, there are associated with the subsequent of hepatocellular carcinoma(HCC). Thus, HGF-HGF receptor signaling might play an important role in carcinogenesis $[163,167]$. PRS-110 (starting at $0.8 \mathrm{mg} / \mathrm{kg}$ and going up to $30 \mathrm{mg} / \mathrm{kg}$ ) specifically binds to Met receptor with high affinity and blocks HGF interaction on ligand-dependent (U87-MG) and ligand-independent (Caki-1) xenograft model [162]. Animals were randomized for the treatment with a novel met inhibitor EMD1214063 $(50 \mathrm{mg} / \mathrm{kg} / \mathrm{d})$, which resulted in a complete regression of the sensitive H1112L met variant-derived tumors[168]. Foretinib, the first multitarget c-met TKI to under clinical investigation, produced a promising benefit in HCC patients [163]. Recently, the chemically-modified monovalent antibody DN30 was found to inhibit ligand- independent activation of the met oncogenic receptor, providing an another target therapy [169-171].

\section{Cytokine receptors had oncogenic mutant variants in cancer}

Growth hormone(GH)/oncogenic GH receptor(GHR) [171174] was associated with growth hormone receptor deficiency [175]; gigantism, acromegaly and cancer risk [176-180]; GHR determines 'cancer- like' features [174]. And GH-releasing hormone GHRH/ GHRH receptor oncogenic signaling [181,182]. Insulin/insulin
receptor/Ros proto-oncogenic receptor homologue, and IGFI,IGF-II/oncogenic receptor PTK IGF-IR linked to physiology and diseases(short statuse, oncogenic transformation process) [182-187]; and IGF-I (Mecasermin) replacement therapy [189-191]. Interesting, the oncogenic mechanism in Ewing sarcoma harboring oncogenic EWS/NR4A3 fusion involves a novel pro-oncogenic IGF/IGF-1 receptor signaling pathway including post-transcriptional depression of IGF signaling by the EWS/Fli1 fusion oncoprotein via miRs [192], and this provide therapeutic targeting anti-IGF-1 receptor antibody in Ewing Sarcoma [193-195].

G-CSF has been used in clinic for more than 2 decades to treat congenital and acquired neutropenias [196-200]. It is highlight the clinical application of G-CSF to children with severe congenital neutropenia(SCN) and especially in patients with neutropenia harboring in the G-CSF receptor(CSF3R) gene, which is correlated to an increased risk for development of MDS and acute myeloid leukemia(AML) [201]. There are two classes of CSF3R mutant variants: truncations of the cytoplasmic domain [202,203] and membrane proximal point mutations including T618I [204]. Truncated CSF3R mutations are the mutant type nearly almost observed in SCN and abnormal signaling of this oncogenic receptor variants in malignant transformation, whereas membrane proximal mutations (particularly T618I) are the predominant mutation type observed in chronic neutrophilic leukemia(CML) and atypical (BCR-ABL negative) chronic myeloid leukemia (aCML), and confer ligand-independent growth [204]. Maxson and colleagues [205] identified activating mutations for CSF3R in 59\% (16/27) of patients with CNL or atypical CML. In vivo, the activating mutation in the CSF3R gene induces hereditary chronic neutrophilia [206]. Mice transplantanted with CSF3R T618Iexpressing hematopoietic cells developed a myeloproliferative disorder [204]. Treatment with the JAK inhibitor ruxolitinib lowered the white blood cells and reduced spleen weight. These results indicate that activating mutant CSF3R is oncogenic [205] and sufficient to drive a myeloproliferayive disorder resembling CML and CNL that is sensitive to pharmacologic JAK inhibition [204].

Another more example is that a translocation $\mathrm{t}(14 ; 19)(\mathrm{q} 32 ; \mathrm{P} 13)$ was involved IGH@ and the cytokine receptor EPOR at 19P13 in two patients with B-cell precursor acute lymphoblastic leukemia (BCPALL) [207,208]. An over 230- and 241-fold increase in the expression of EPOR were observed in 2 patients at diagnostic and relapse samples respectively. The EPOR-IGH/IGK chain fusions result in truncation of the cytoplasmic tail of EGFR at residues similar to the mutant EPOR in PFCP, with preservation of the proximal tyrosine essential for receptor activation and loss of distal regulatory residues. Expression of truncated EPOR in mouse B cell progenitors induced ALL in vivo. The data implicate oncogenic erythropoietin receptor in role of both benign erythrocytosis and malignancy [209,210]. Moreover, mutation of erythropoitin receptor (EPOR) gene was associated with primary familial and congenital polycythemia(PFCP).Truncated mutations of 59 to 84 amino acids of EPOR at c-terminus lead to loss of the intracellular cytoplasmic tail of the receptor, and prolonged proliferative signal resulting in hypersensitivity (5-10 fold increased sensitivity) to erythropoitin, and prolonged activity of JAK2 kinase and STAT5 activity [211-214].The leukemic cells with oncogenic EPOR fusions were sensitive to JAK-STAT inhibition, suggesting a therapeutic option in high-risk ALL.

Accumulated studies, constitutive activation of cytokine interleukin-2(IL-2) gene can induce autocrine growth of IL-2producing leukemic cells in adult T-cell leukemia [215], in vitro 
transformation and tumorigenicy of T cells [216-219], and tumor cells bearing IL-2-BCM fusion in a T cell lymphoma with $\mathrm{t}(4 ; 16)(\mathrm{q} 26 ; \mathrm{p} 13)$ translocation [220]. IL-2 binds to IL-2 receptor a(IL-2Ra) and rc subunit of the IL-2 receptor(IL-2RG) sharing with other cytokine receptor superfamily (including IL-7 receptor, IL-21 receptor) that receptor complex transduces growth and differentiation signals [221]. Under physiological condition, IL-2 appears to act on antigen-specific proliferation of T lymphocytes, immune thymocytes, B-lymphocytes, natural killer cells(NK cells) and lymphokine-activated killer cells(LAK cells), which linked to adoptive immune therapy [222].

In vitro nude mice, fibroblasts transfected with a chimera molecule containing the extracellular IL-2 binding domain of the IL-2R cDNA and the transmembrane and intracellular kinase domain of the EGF receptor cDNA, were morphologically transformed and produced rapidly growing tumor [223]. Moreover, retroviral expression of IL2RG restore signaling by IL-7 receptor to X-SCID precursor cells in T-cell progression to the pro-leukemic effects of ectopic LMO2 [224]. Recently, the chromosomal translocation $t(5 ; 9)$ ( $\mathrm{q} 13 ; \mathrm{q} 22)$ in peripheral $\mathrm{T}$ cell lymphoma generating the interleukin 2 inducible $\mathrm{T}$ cell kinase(ITK)-spleen tyrosine kinase(SYK) fusion kinase mimics a $\mathrm{T}$-cell receptor signal and drives oncogenesis in mouse models.

Activation of the interleukin-3(IL-3) gene by the enhancer of the $\mathrm{IgH}$ fusion leads to the overexpression of IL-3 gene product in 2 cases of acute lymphocytic leukemia with $\mathrm{t}(5 ; 14)(\mathrm{q} 31 ; \mathrm{q} 21)$ translocation[225]. Serum IL-3 correlated with the clinical cause. When the patient's leukemic cell burden was highest (WBC 116,500/ul, lymphoblasts $33,785 / \mathrm{ul})$, the serum IL-3 level was highest $(799,5 \mathrm{pg} / \mathrm{ml})$; whereas complete remission(WBC 123,00/ul, lymphoblasts 0/ul), serum IL-3 levels decreased to $105,1 \mathrm{pg} / \mathrm{ml}$. Therefore, overexpression of IL-3 gene coupled with the presence of aberrant IL-3 receptor in these cells could account for oncogenic effects for proliferatative advantage and may play a central role in the pathogenesis of leukemia [225,226]. Aberrant presence of cysteine residues was shown to induce homodimerization of mutant interleukin-7 receptor(IL-7R), which drive constitutive signaling via JAK1 and independently of IL-7, rc or JAK3[227], promoting cell transformation. This abnormality is involved in $-10 \%$ human pediatric $\mathrm{T}$-cell leukemogenesis, paving the way for therapeutic targeting oncogenic IL-7R-mediated signaling in T-ALL [228-230]. Interleukin-21 receptor (IL-21R) is capable of signal transduction through homodimerization or potentially heterodimerization with IL$2 \mathrm{R}$ gamma. IL-21 and IL-21R not only regulates proliferation of mature $\mathrm{B}$ cells and $\mathrm{T}$ cells in response to activating stimuli but also mediate expansion of NK population from bone marrow. The gene for IL-21R is found the partner of BCL6 in $\mathrm{t}(3 ; 16)(\mathrm{q} 27 ; \mathrm{p} 11)$, which is recurrently observed in diffuse large B-cell lymphoma and a lymphoma cell line YM [231].This IL-21R/BCL6 fusion gene is clearly associated with lymphoid cell origin.

\section{Conclusion}

To date, antibodies that target oncogenic receptors are often targeted toward lysosome [232] or blockade of translocation from the endoplasmic reticulum to the cell surface of specific antigens such as vascular endothelial growth factor receptors(VEGFR2) or Tie2 [233]. For instance, targeting cells with biotinylated ligands and addition of streptavidin efficiently targets trastuzumab to lysosome and this crosslinking of trastuzumab increased lysosomal degradation of its cognate oncogenic receptor Her2 in breast cancer cell lines [232]. Another burgeoning class of targeted chemotherapies called antibodydrug conjugates(ADCs).This ADCs that have demonstrated sufficient efficacy to gain and retain clinical approved are ado-tratuzumab emtansine (brand name Kadcyla) and brentuximab vedotin (brand name Adcetris) [234]. The auristatin-based antibody-drug conjugate BAY1187982 is for the treatment of FGFR2-positive solid tumors [195]. Another, the nicotinic acetylcholine receptor a7- nAchR (toxicology) is the oncogenic receptor, which mediated nicotine(NNK and NNN) oncogenic signaling in an important role in the initiation and progression of cancer including lung cancer and this oncogenic response was in parallel with the mutagenic and cytotoxic effects of tobacco smoke to promote the growth and angiogenesis of the tobacco related cancers [235]. Thus nAchRs yield new targets for the prevention and treatment of tobacco related cancers. Therefore, downregulating oncogenic receptors may be useful paradigm and perspective in our better understanding of clinical cancer biology [236-258].

\section{Acknowledgement}

We wish to thank Prof. T. Taniguchi in University of Tokyo in Japan, Nobel Laureates Prof. Ferid Murad in University of Texas Health Center in USA and UNESCO Science Laureates Prof. Atta-urrahman in international center for chemical and biological sciences, university of karachi in Pakistan for their valuable help. I especially want to thank my friend $\mathrm{Mr}$. Xu for his precious time and patience in long preparing the article.

\section{References}

1. George Zhu (1989-91) Oncogenic receptor hypothesis. VOA (Voice of America) 12: 31

2. George Zhu (1993-2010) A retrospective study of the combination of chemotherapy with phytohemagglutinin (PHA, inducing the generation of interleukin 2) in advanced cancer (1997, unpublished data). Long follow up of patients with advanced cancers after chemotherapy with traditional medicine (2000). A further study of patients with advanced cancer after chemotherapy with traditional chinese medicine. JCCM 2: 618623 . Five to ten years' survivors of patients with advanced cancers after chemotherapy with traditional chinese medicine, JCCM 4: 512-519 (EBSCO). Use of chemotherapy and traditional medicine for advanced cancers:A retrospective study of 68 patients JCCM 5: 343-350.

3. George Zhu, Musumeci F, Byrne P (2013) Induction of thyroid neoplasm following plant medicine marine algae (sargassum): a rare case and literature. Curr Pharm Biotechnol 14: 859-863.

4. Zhu G (2013) Novel treatment of acute promyelocytic leukemia: $\mathrm{As}_{2} \mathrm{O}_{3}$, retinoic acid and retinoid pharmacology. Curr Pharm Biotechnol 14: 849-858. [Crossref]

5. George Zhu, Dong JX, Dharmadhikari D (2013) In, Natural products from traditional medicine antitumor compound in advanced cancers. Proceeding of BIT's 11th Annual Congress of International Drug Discovery Science and Technology p: 477.

6. George Zhu (2014) In Discovery of the molecular basis of retinoic acid action (retinoid signalling)-A genetic regulation of eukaryotes in transcription. Proceedings of 3 nd biotechnology world congress, Duibai, UAE, pp: 97-98.

7. George Zhu, Ali-AKbar Saboor-Yaraghi (2015) In oncogenic receptor: from molecular physiology to diseases. Abstract in BIT's 8th Annual World Cancer Congress p: 494.

8. Chomienne C, Ballerini P, Balitrand N, Huang ME, Krawice I, et al. (1990) The retinoic acid receptor alpha gene is rearranged in retinoic acid-sensitive promyelocytic leukemias. Leukemia 4: 802-807. [Crossref]

9. De Thé H, Lavau C, Marchio A, Chomienne C, Degos L, et al. (1991) The PML-RAR alpha fusion mRNA generated by the $t(15 ; 17)$ translocation in acute promyelocytic leukemia encodes a functionally altered RAR. Cell 66: 675-684. [Crossref]

10. Neil JC, Fulton R, McFarlane R, Rigby M, Stewart M, Terry A, et al. (2004) Receptormediated leukemogenesis: hypothesis revisited. Br J Cancer Suppl 9: 76-79. [Crossref]

11. Strzadala L, Miazek A, Mat uszyk J, Kisielow P (1996) Role of thymic selection in the development of thymic lymphomas in TCR transgenic mice. Int Immunol 9:127-38. [Crossref]

12. Mehlen P and Bredesen DE (2004) The dependence receptor hypothesis. Apoptosis 9: $37-49$.

13. Jacobs H, Ossendorp F, de Vries E, (1996) Oncogenic potential of a pre-T cell receptor 
lacking the TCRbeta variable domain. Oncogene 12: 2089-2099. [Crossref]

14. Cui YZ, Onozawa M, Garber HR, Samsel L, Wang Z, et al. (2015) Thymic expression of a T-cell receptor targeting a tumor-associated antigen coexpressed in thymus induces T-ALL. Blood 125: 2958-67. [Crossref]

15. Denny CT, Yoshikai Y, Mak TW, Smith SD, Hollis GF, et al. (1986) A chromosome 14 inversions in a T-cell lymphoma is caused by site-specific recombination between immunoglobulin and T-cell receptor loci. Nature 320: 549-551. [Crossref]

16. Davey MP (1988) Juxtaposition of the T-cell receptor alpha-chain locus(14q11) and a region(14q32) of potential importance in leukemogenesis by a 14:14 translocation in a patient with T-cell chronic lymphocytic leukemia and ataxia-telangiectasia. Proc Natl Acad Sci 85: 9287-9291.

17. Corcos D (2011) Oncogenic potential of the B-cell antigen receptor and its relevance to heavy chain disease and other B-cell neoplasias: a new model. Research in Immunology 140: $543-553$

18. Corcos D, Osborn MJ, Matheson LS (2011) B-cell receptors and heavy chain diseases: guilt by association. Blood 117: 6991-6998.

19. Friedman DR, Weinberg JB (2013) Inhibition of B-cell receptor signalling as a therapeutic strategy for treatment of CLL. The Haematologist 13:5.

20. Yarden Y, Peles E (1991) Biochemical analysis of the ligand for the neu oncogenic receptor. Biochemistry 30: 3543-3550. [Crossref]

21. LeVea CM, Myers JN, Dougall WC, Qian X, Greene MI (1993) A structural and kinetic comparison of proto-oncogenic and oncogenic neu holo-receptors expressed in insect cells. Receptor 3: 293-309. [Crossref]

22. Tzahar E, Yarden Y (1998) The ErbB-2/HER2 oncogenic receptor of adenocarcinomas: from orphanhood to multiple stromal ligands. Biochim Biophys Acta 1377: M25-37. [Crossref]

23. Houliston RS, Hodges RS, Sharom FJ, Davis JH (2004) Characterization of the protooncogenic and mutant forms of the transmembrane region of Neu in micelles. $J$ Biol Chem 279: 24073-24080. [Crossref]

24. Jonckhere (2012) The Mucin MUC4 and its membrane partner ErbB2 regulate biological properties of human CAPAN-2 pancreatic cancer cells via different signaling pathways. PLos One 7: e32232.

25. Nicolas S (2015) The oncogenic receptor ErbB2 modulates gemcitabine and irinotecin $\mathrm{SN}-38$ chemoresistance of human pancreatic cancer cells via hCNT1 transporter and multidrug resistance associated protein MRP-2. Oncotarget 6:10853-10861.

26. Serra V, Vivancos A, Puente XS, Felip E, Silberschmidt D, et al. (2013) Clinica response to a lapatinib-based therapy for a Li-Fraumeni syndrome patient with a novel HER2V659E mutation. Cancer Discov 3: 1238-12344.

27. Al-Nedawi K, Meehan B, Micallef J, Lhotak V, May L, et al. (2008) Intercellular transfer of the oncogenic receptor EGFRvIII by microvesicles derived from tumour cells. Nat Cell Biol 10: 619-624. [Crossref]

28. Robinson R (2008) Tumor cells share oncogenic receptors. J Cell Biol (JCB) 181: 570.

29. Santos J, Mesquita D, Barros-Silva JD, Jerónimo C, Henrique R, et al. (2015) Uncovering potential downstream targets of oncogenic GRPR overexpression in prostate carcinomas harboring ETS rearrangements. Oncoscience 2: 497-507. [Crossref]

30. [Crossref] Willard MD, Lajiness ME, Wulur IH, Feng B, Swearingen ML, et al. (2012) Somatic mutations in CCK2R alter receptor activity that promote oncogenic phenotypes. Mol Cancer Res 10: 739-749.

31. Denzel S, Maetzel D, Mack B, Eggert C, Bärr G, et al. (2009) Initial activation of EpCAM cleavage via cell-to-cell contact. BMC Cancer 9: 402. [Crossref]

32. Green S, Chambon P (1986) A superfamily of potentially oncogenic hormone receptors. Nature 324: 615-617. [Crossref]

33. Elangovan S, Ramachandran S, Venkatesan N, Ananth S, Gnana-Prakasam JP, et al. (2011) SIRT1 is essential for oncogenic signaling by estrogen/estrogen receptor $\infty$ in breast cancer. Cancer Res 71: 6654-6664. [Crossref]

34. Russo IH, Russo J (1998) Role of hormones in mammary cancer initiation and progression. J Mammary Gland Biol Neoplasia 3: 49-61. [Crossref]

35. Dickson RB, McManaway ME, Lippman ME (1986) Estrogen-induced factors of breast cancer cells partially replace estrogen to promote tumor growth. Science 232: 1540-1543. [Crossref]
36. Dickson RB and Stancel GM (2010) Estrogen receptor-mediated processes in norma and cancer cells. In: Cavalieri E and Rognan E (Eds) JNCI Monograph: Estrogen as endogenous carcinogens in breast and prostate. Oxford University Press, Oxford pp: 135-145.

37. Russo J, Lareef MH, Tahin Q, Hu YF, Slater C, et al. (2002) 17Beta-estradiol is carcinogenic in human breast epithelial cells. J Steroid Biochem Mol Biol 80: 149-162.

38. Russo J, Fernandez SV, Russo PA, Fernbaugh R, Sheriff FS, et al. (2006) 17-Betaestradiol induces transformation and tumorigenesis in human breast epithelial cells. FASEBS 20: 1622-1634.

39. Abramson W, Warshawsky H (1948) Cancer of the breast in the male, secondary to estrogenic administration; report of a case. J Urol 59: 76-82. [Crossref]

40. Santen R, Cavalieri E, Rogan E, Russo J, Guttenplan J, et al. (2009) Estrogen mediation of breast tumor formation involves estrogen receptor-dependent, as well as independent, genotoxic effects. Ann N Y Acad Sci 1155: 132-140. [Crossref]

41. Yue W, Yager JD, Wang JP, Jupe ER, Santen RJ (2013) Estrogen receptor-dependent and independent mechanisms of breast cancer carcinogenesis. Steroids 78: 161-170. [Crossref]

42. Singh RR, Kumar R (2005) Steroid hormone receptor signalling in tumorigenesis. $J$ Cell Biochem 96: 490-505. [Crossref]

43. Clarke RB1 (2004) Human breast cell proliferation and its relationship to steroid receptor expression. Climacteric 7: 129-137. [Crossref]

44. Bocchinfuso WP1, Korach KS (1997) Mammary gland development and tumorigenesis in estrogen receptor knockout mice. J Mammary Gland Biol Neoplasia 2: 323-334. [Crossref]

45. Tekmal RR, Liu YG, Nair HB, Jones J, Perla RP, et al. (2005) Estrogen receptor alpha is required for mammary development and the induction of mammary hyperplasia and epigenetic alterations in the aromatase transgenic mice. J Steroid Biochem Mol Biol 95: 9-15. [Crossref]

46. Tilli MT, Frech MS, Steed ME, Hruska KS, Johnson MD, et al. (2003) Introduction of ERa into the tTA/TAg conditional mouse model precipitates the development of estrogen-responsive mammary adenocarcinoma. Am J Pathol 163: 1713-1719.

47. Couse JF, Davis VL, Hanson RB, Jefferson WN, McLachlan JA (1997) Accelerated onset of uterine tumours in transgenic mice with aberrant expression of the estrogen receptor after neonatal exposure to DES. Mol Carcinog 19: 236-242.

48. Davis VL (2012) Expression of a dominant negative estrogen receptor alpha variant in transgenic mice accelerates uterine cancer induced by the potent estrogen diethylstilbestrol. Reprod Toxicol 34: 512-521.

49. Wesledge G, McGuire WL (1983) Mutations in the estrogen and androgen receptors may contribute to the conversion of steroid-dependent breast tumors and prostate tumors to hormone-independent growth. Adv Cancer Res 38: 61.

50. Fuqua SAW, Wiltschke C, Zhang QX, Borg A, Castles CG, et al. (2000) A hypersensitive estrogen receptor-alpha mutation in premalignant breast lesions. Cancer Res 60: 40264029.

51. Herynk MH (2010) A hypersensitive estrogen receptor alpha mutation that alters dynamic protein interation. Breast Cancer Res Treat 122: 381-393.

52. Veeraraghavan J, Tan Y, Cao XX, Kim JA, Wang X, et al. (2014) Recurrent ESR1CCDC170 rearrangements in an aggressive subset of oestrogen receptor-positive breast cancers. Nat Commun 5: 4577. [Crossref]

53. Giltnane JM, Balko JM, Stricker TL, Young C, Estrada MV, et al. (2015) Recurrent ESR1 fusion transcripts are associated with endocrine resistance in estrogen receptor positive, HER2 negative breast cancer. Abstract PD6-3 in Thirty-seventh Annual CTRC-AACR San Antonio Breast Cancer Symposium, December 9-13,2014, San Antonio, TX, Cancer Res 75.

54. Frech MS, Halama ED, Tilli MT, Singh B, Gunther EJ, et al. (2005) Deregulated estrogen receptor alpha expression in mammary epithelial cells of transvenic mice results in the development of ductal carcinoma in situ. Cancer Res 65: 681-685.

55. Takeshita T, Yamamoto Y, Yamamoto-Ibusuki M, Inao T, Sueta A, et al. (2015) Droplet digital polymerase chain reaction assay for screeing of ESR1 mutations in 325 breast cancer specimens. Transl Res 166: e5542.

56. Weir HM, Bradbury RH, Lawson M, Rabow AA, Buttar D, et al. (2016) AZD9496: An Oral Estrogen Receptor Inhibitor That Blocks the Growth of ER-Positive and ESR1Mutant Breast Tumors in Preclinical Models. Cancer Res 76: 3307-3318. [Crossref]

57. Cunha GR, Chung LWK (1981) Stromal-epithelial interactions-I. Induction of prostatic 
phenotype in urothelium of testicular feminized(Tfm/y) mice. J Steroid Biochem 14: 1317-1324.

58. Izumi K, Mizokami A, Lin WJ, Lai KP, Chang C (2013) Androgen receptor roles in the development of benign prostate hyperplasia. Am J Pathol 182: 1942-1949. [Crossref]

59. Berger R, Febbo PG, Majumder PK, Zhao JJ, Mukherjee S, et al. (2004) Androgeninduced differentiation and tumorigenicity of human prostate epithelial cells. Cancer Res 64: 8867-8875. [Crossref]

60. Stanbrough M, Leav I, Kwan PW, Bubley GJ, Balk SP (2001) Prostatic intraepithelial neoplasia in mice expressing an androgen receptor transgene in prostate epithelium. Proc Natl Acad Sci U S A 98: 10823-10828. [Crossref]

61. Mononen N, Syrjäkoski K, Matikainen M, Tammela TL, Schleutker J, et al. (2000) Two percent of Finnish prostate cancer patients have a germ-line mutation in the hormonebinding domain of the androgen receptor gene. Cancer Res 60: 6479-6481. [Crossref]

62. Koivisto PA, Hyytinen ER, Matikainen M, Tammela TL, Ikonen T, et al. (2004) Germline mutation analysis of the androgen receptor gene in Finnish patients with prostate cancer. $J$ Urol 171: 431-433. [Crossref]

63. Harris SE, Rong Z, Harris MA (1990) Androgen receptor in human prostate carcinoma LNCaP/Adep cells contains a mutation which alters the specificity of the steroiddependent transcriptional activation region. In: Bell L (Ed) Proceedings of the 72nd Annual Meeting of the Endocrine Society: Atlanta(GA), Bethesda(MD): The Endocrine Society.

64. Veldscholte J, Ris-Stalpers C, Kuiper GG, Jenster G, Berrevoets C, et al. (1990) A mutation in the ligand binding domain of the androgen receptor of human $\mathrm{LNCaP}$ cells affects steroid binding characteristics and response to anti-androgens. Biochem Biophys Res Commun 173: 534-540. [Crossref]

65. Culing Z (1993) Mutant androgen receptor detected in an advanced-stage prostatic carcinoma is activated by adenal androgens and progesterone. Mol Endocrinol 7: 15411550.

66. Gaddipati JP, McLeod DG, Heidenberg HB, Sesterhenn IA, Finger MJ, et al. (1994) Frequent detection of codon 877 mutation in the androgen receptor gene in advanced prostate cancers. Cancer Res 54: 2861-2864. [Crossref]

67. Taplin ME, Bubley GJ, Shuster TD, Frantz ME, Spooner AE, et al. (1995) Mutation of the androgen-receptor gene in metastatic androgen-independent prostate cancer. $N E n g l$ J Med 332: 1393-1398. [Crossref]

68. Suzuki H, Akakura K, Komiya A, Aida S, Akimoto S, et al. (1996) Codon 877 mutation in the androgen receptor gene in advanced prostate cancer: relation to antiandrogen withdrawal syndrome. Prostate 29: 153-158. [Crossref]

69. Southwell J, Chowdhury SF, Gottlieb B, Beitel LK, Lumbroso R, et al. (2008) An investigation into $\mathrm{CAG}$ repeat length variation and $\mathrm{N} / \mathrm{C}$ terminal interactions in the T877A mutant androgen receptor found in prostate cancer. J Steroid Biochem Mol Biol 111: 138-146. [Crossref]

70. Newmark JR1, Hardy DO, Tonb DC, Carter BS, Epstein JI, et al. (1992) Androgen receptor gene mutations in human prostate cancer. Proc Natl Acad Sci U S A 89: 63196323. [Crossref]

71. Nyquist MD, Li Y, Hwang TH, Manlove LS, Vessella RL, et al. (2013) TALENengineered AR gene rearrangements reveal endocrine uncoupling of androgen receptor in prostate cancer. Proc Natl Acad Sci USA 110: 17492-17497. [Crossref]

72. Tepper CG, Boucher DL, Ryan PE, Ma AH, Xia L, et al. (2002) Characterization of a novel androgen receptor mutation in a relapsed CWR22 prostate cancer xenograft and cell line. Cancer Res 62: 660.

73. Shi XB, Xue L, Tepper CG, Gandout-Edwards R, Ghoch P, et al. ( 2007) The oncogenic potential of a prostate cancer-derived androgen receptor mutant. The prostate 67: 591602.

74. Kung HJ, Evans CP (2009) Oncogenic activation of androgen receptor. Urol Oncol 27: 48-52. [Crossref]

75. Sun SH, Sprenger CCT, Vessella RL, Haugk K, Soriano K, et al. (2010) Castration resistance in human prostate cancer is conferred by a frequently occurring androgen receptor splice variant. $J$ Clin Invest 120: 2715-2730.

76. Young L, Creevey L, Ali A, Hill ADK, Mcllroy M (2015) Investigation into the oncogenic potential of the androgen receptor in aromatase inhibitor resistant breast cancer. In Thirty- Seventh Annual CTRC-AACR San Antonio Breast Cancer Symposium, San Antonio, TX

77. Liang M, Adisetiyo H, Liu X, Liu R, Gill P, et al. (2015) Identification of androgen receptor splice variants in the pten deficient murine prostate cancer model. PLoS One
10: $\mathrm{e} 0131232$.

78. Gucalp A (2013) Phase II trial of bicalutamide in patients with androgen receptorpositive, estrogen receptor-negative metastatic breast cancer. Clin Cancer Res 19: $5505-5512$

79. Coindet J (1821) Nouvelles recherches sur les effects de l'iode,et sur les cautions survere dansle traitment du goitre par ce nuveau remide. Ann Chimie Phys 16: 252-266.

80. Goldberg RC, Chaikoff IL (1952) Induction of thyroid cancer in the rat by radioactive iodine. AMA Arch Pathol 53: 22-28. [Crossref]

81. Suzuki H, Higuchi T, Hashimoto H, Otaki S (1962) A case of endemic goiter along the seashores of Hidaka District, Hokkaido. Jpn J Med Sci Biol 51: 781-786. [Crossref]

82. Mussig K, Thamer C, Bares R, Lipp HP, Haring HU, et al. (2006) Iodine-induced thyrotoxicosis after ingestion of kelp-containing tea. J Gen Intern Med 21: C11-C14.

83. Horn-Ross PL1, Morris JS, Lee M, West DW, Whittemore AS, et al. (2001) Iodine and thyroid cancer risk among women in a multiethnic population: the Bay Area Thyroid Cancer Study. Cancer Epidemiol Biomarkers Prev 10: 979-985. [Crossref]

84. Giusti F1, Falchetti A, Franceschelli F, Marini F, Tanini A, et al. (2010) Thyroid cancer current molecular perspectives. J Oncol 2010: 351679. [Crossref]

85. Michikawa T, Inoue M, Shimazu T, Sawada N, Iwasaki M, et al. (2012) Seaweed consumption and the risk of thyroid cancer in women: the Japan Public Health Centerbased prospective study. Eur J Cancer Prev 21: 254-260.

86. Schneider DF1, Chen H (2013) New developments in the diagnosis and treatment of thyroid cancer. CA Cancer J Clin 63: 374-394. [Crossref]

87. Chandrasekaran M, Ramadevi K (2013) Thyromegaly and iodine nutritional status in a tertiary care hospital in South India. Indian J Endocrinol Metab 17: 260-264. [Crossref]

88. Choi WJ, Kim J (2014) Dietary factors and the risk of thyroid cancer: a review. Clin Nutr Res 3: 75-88. [Crossref]

89. Varricchio L (2011) The dominant negative beta isoform of the glucocorticoid receptor is uniquely expressed in erythroid cells expanded from polycythemia vera patients. Blood 118: 425-423

90. Mikosz CA, Brickley DR, Sharkey MS, Moran TW, Conzen SD (2001) Glucocorticoid receptor-mediated protection from apoptosis is associated with induction of the serine/ threonine survival kinase gene, sgk-1. J Biol Chem 276: 16649-16654. [Crossref]

91. Melhem A, Yamada SD, Fleming GF, Delgado B, Brickley DR, et al. (2009) Administration of glucocorticoids to ovarian cancer patients is associated with expression of the anti-apoptotic genes SGK1 and MKP1/DUSP1 in ovarian tissues. Clin Cancer Res 15: 3196-3204. [Crossref]

92. Isikbay M, Otto K, Kregel S, Kach J, Cai Y, et al. (2014) Glucocorticoid receptor activity contributes to resistance to androgen-targeted therapy in prostate cancer. Horm Cancer 5: 72-89. [Crossref]

93. Mirand EA, Reiniiard MC, Goltz HL, Moore GE (1953) Development of sarcomas in Marsh-Albino mice following injection of desoxycorticosterone acetate(DCA) in sesame oil. Proc Soc Exper Biol and Med 83: 14-17.

94. Lien HC, Lu YS, Cheng AL, Chang WC, Jeng YM, et al. (2006) Differential expression of glucocorticoid receptor in human breast tissue and related neoplasms. J Pathol 209: 317-327. [Crossref]

95. Moutsatsou P, Papavassiliou AG (2008) The glucocorticoid receptor signalling in breast cancer. J Cell Mol Med 12: 145-163. [Crossref]

96. Vilasco M, Communal L, Mourra N, Courtin A, Forgez P, et al. (2011) Glucocorticoid receptor and breast cancer. Breast Cancer Res Treat 140: 1-10. [Crossref]

97. Krishnan AV, Zhao XY, Swami S, Brive L, Peehi DM, et al. (2002) A glucocorticoidresponsive mutant androgen receptor exhibits unique ligand specificity: therapeutic implications for androgen-independent prostate cancer. Endocrinology 143: 18891900 .

98. Simanainen U, Lampinen A, Henneicke H, Brennan TC, Heinevetter U, et al. (2011) Long-term corticosterone treatment induced lobe-specific pathology in mouse prostate. Prostate 71: 289-297. [Crossref]

99. Ebisawa T, Tojo K, Tajima N, Kamio M, Oki Y, et al. (2008) Immunohistochemica analysis of 11-beta -hydroxysteroid dehydrogenase type 2 and glucocorticoid receptor in subclinical Cushing's disease due to pituitary macroadenoma. Endocrine Pathology 19: 252-260.

100. Karl M (1996) Nelson's syndrome associated with somatic frame shift mutation in the glucocorticoid receptor gene. J Clin Endocrinol Metab 81: 124-129. 
101. Newfield RS, Kalaitzoglou G, Licholai T, Chilton D, Ashraf J, et al. (2000) Normocorticolemic Cushing's syndrome initially presenting with increased glucocorticoid receptor number. J Clin Endocrinol Metab 85: 14-21.

102. Johanssen S and Allolio B (2007) Mifepristone (RU486) in Cushing's syndrome. Eur J Endocrinol 157: 561-569.

103. Skor MN, Wonder EL, Kocherginsky M, Goyal A, Hall BA, et al. (2013) Glucocorticoid receptor antagonism as a novel therapy for triple-negative breast cancer. Clin Cancer Res 19: 6163-6172. [Crossref]

104. Risch HA (1998) Hormonal etiology of epithelial ovarian cancer, with a hypothesis concerning the role of androgens and progesterone. J Natl Cancer Inst 90: 1774-1786. [Crossref]

105. Althuis MD, Fergenbaum JH, Garcia-Closas M, Sherman ME (2004) Etiology of hormone receptor-defined breast cancer: A systematic review of the literature. Cancer Epidemiol Biomarkers Prev 10: 1558-1568. [Crossref]

106. Richards JS, Farookhi R (1978) Gonadotrophins and ovarian-follicular growth. Clin Obstet Gynaecol 5: 363-373. [Crossref]

107. Choi JH, Choi KC, Auersperg N, Leung PCK (2004) Overexpression of folliclestimulating hormone receptor activates oncogenic pathways in preneoplastic ovarian surface epithelial cells. J Clin Endocrinol Metab 89: 5508-5516. [Crossref]

108. Hull ME, Kriner M, Schneider E, Maiman M (1996) Ovarian cancer after successful ovulation induction: a case report. J Reprod Med 41: 52-54. [Crossref]

109. Shushan A, Paltiel O, Iscovich J, Elchalal U, Peretz T, et al. (1996) Human menopausal gonadotropin and the risk of epithelial ovarian cancer. Fertil Steril 65 : 13-18. [Crossref]

110. Brinton LA, Lamb EJ, Moghissi KS, Scoccia B, Althuis MD, et al. (2004) Ovarian cancer risk after the use of ovulation-stimulating drugs. Obstet Gynecol 103: 11941203. [Crossref]

111. Hauksdóttir H, Privalsky ML (2001) DNA recognition by the aberrant retinoic acid receptors implicated in human acute promyelocytic leukemia. Cell Growth Differ 12: 85-98. [Crossref]

112. Grignani F, Ferrucci P, Testa U, Talamo G, Fagioli M, et al. (1993) The acute promyelocytic leukemia-specific PML-RARa fusion protein inhibits differentiation and promotes survival of myeloid precursor cells. Cell 74: 423-431.

113. Rousselot P, Hardas H, Patel A, Guidez F, Gaken J, et al. (1994) The PML-RARa gene product of the $\mathrm{t}(15 ; 17)$ translocation inhibits retinoic acid-induced granulocytic differentiation and mediated transactivation in human myeloid cells. Oncogene 9 : $545-551$.

114. Yoshida H, Kitamura K, Tanaka K, Omura S, Miyazaki T, et al. (1996) Accelerated degradation of PML-retinoic acid receptor alpha (PML-RARa) oncoprotein by alltrans-retinoic acid in acute promyelocytic leukemia, possible role of the proteasome pathway. Cancer Res 56: 2945-2948.

115. Kitareewan S, Pitha-Rowe I, Sekula D, Lowrey CH, Nemeth MJ, et al. (2002) UBE1L is a retinoid target that triggers PML/RARalpha degradation and apoptosis in acute promyelocytic leukemia. Proc Natl Acad Sci USA 99: 3806-3811. [Crossref]

116. Segalla S1, Rinaldi L, Kilstrup-Nielsen C, Badaracco G, Minucci S, et al. (2003) Retinoic acid receptor alpha fusion to PML affects its transcriptional and chromatinremodeling properties. Mol Cell Biol 23: 8795-8808. [Crossref]

117. Carbone R, Botrugno OA, Ronzoni S, Insinga A, Di Croce L, et al. (2006) Recruitment of the histone methyltransferase SUV39H1 and its role in the oncogenic properties of the leukemia-associated PML-retinic acid receptor fusion protein. Mol Cell Biol 26: 1288-1296.

118. Nasr R, Guillemin MC, Ferhi O, Soilihi H, Peres L, et al. (2008) Thé HEradication of acute promyelocytic leukemia-initiating cells through PML-RARA degradation. Nature Medicine 14: 1333-1342.

119. Marstrand TT (2010) A conceptual framework for the identification of candidate drugs and drug targets in acute promyelocytic leukemia. Leukemia 24: 1265.

120. Lallemand-Breitenbach V, de Thé H (2010) A new oncoprotein catabolism pathway. Blood 116: 2200-2201. [Crossref]

121. Podhorecka M, Macheta A (2013) Acute promyelocytic leukemia--modern approach to disease pathogenesis and differentiation treatment. Postepy Hig Med Dosw 67: 1083-1089.

122. Dos Santos GA, Kats L, Pandolfi PP (2013) Synergy against PML-RARa: targeting transcription, proteolysis, differentiation, and self-renewal in acute promyelocytic leukemia. J Exp Med 210: 2793-2802. [Crossref]
123. Humbert M (2014) The tumor suppressor gene DAPK2 is induced by myeloid transcription factors pu. 1 and c.EBPa dueing granulocytic differentiation but repressed by PML-RARa in APL. J Leuk Biol 95: 83-93.

124. Braekeleer E, Douet-Guilbert N, De Braekeleer M (2014) RARA fusion genes in acute promyelocytic leukemia: a review. Expert Rev Hematol 7: 347-357. [Crossref]

125. Rietveld LE, Caldenhoven E, Stunnenberg HG (2001) Avian erythroleukemia: a model for corepressor function in cancer. Oncogene 20: 3100-3109. [Crossref]

126. Cohen S, Ushiro H, Stoscheck C, Chinkers M (1982) A native 170,000 epidermal growth factor receptor-kinase complex from shed plasma membrane vesicles. $J$ Biol Chem 257: 1523-1531. [Crossref]

127. Brown GL, Nanney LB, Griffen J, Cramer AB, Yancey JM, et al. (1989) Enhancement of wound healing by topical treatment with epidermal growth factor. $N$ Engl J Med 321: 76-79. [Crossref]

128. Zandi R, Larsen AB, Andersen P, Stockhausen MT, Poulsen HS (2007) Mechanisms for oncogenic activation of the epidermal growth factor receptor. Cell Signal 19: 20132023. [Crossref]

129. Laisney JA, Mueller TD, Schartl M, Meierjohann S (2013) Hyperactivation of constitutively dimerized oncogenic EGF receptors by autocrine loops. Oncogene 32 : 2403-2411. [Crossref]

130. Glynn SA, Boersma BJ, Dorsey TH, Yi M, Yfantis HG, et al. (2010) Increased NOS2 predicts poor survival in estrogen receptor-negative breast cancer patients. J Clin Invest 120: 3843-3854. [Crossref]

131. Kim Y, Apetri M, Luo B, Settleman JE, Anderson KS (2015) Differential Effects of Tyrosine Kinase Inhibitors on Normal and Oncogenic EGFR Signaling and Downstream Effectors. Mol Cancer Res 13: 765-774. [Crossref]

132. Ullrich A (1992) Growth factor receptors in oncogenesis. The American Association for Cancer Research Annual Meeting 33: 589-590.

133. O'Connor R (2008) Concealed cargo within the tumor microenvironment: microvesicles disseminate oncogenic receptors among cancer cells. Cancer Biol Ther 7: 1350-1351. [Crossref]

134. Gabitova L, Gorin A, Astsaturov I (2014) Molecular pathways: sterols and receptor signaling in cancer. Clin Cancer Res 20: 28-34. [Crossref]

135. Shimizu N and Kondo I (1982) Hyperproduction of EGF receptor in human A431 cell is regulated by a translocation chromosome, $\mathrm{t}(7 ; 11)(\mathrm{p} 22 ; \mathrm{q} 23)$. Cytogenetics and Cell Genetics 32: 316-317.

136. Merlino GT, Xu YH, Ishii S, Clark AJ, Semba K, et al. (1984) Amplification and enhanced expression of the epidermal growth factor receptor gene in A431 human carcinoma cells. Science 224: 417-419. [Crossref]

137. Ullrich A, Coussens J, Hayflick JS, Dull TJ, Gray A, et al. (1984) Human epiderma growth factor receptor cDNA sequence and aberrant expression of the amplified gene in A431 epidermoid carcinoma cells. Nature 309: 418-425.

38. Santon JB, Cronin MT, MacLeod CL, Mendelsohn J, Masui H, et al. (1986) Effect of epidermal growth factor receptor concentration on tumorigenicity of A431 cells in nude mice. Cancer Res 46: 4701-4705. [Crossref]

139. Kamata N, Chida K, Rikimaru K, Horikoshi M, Enomoto S, et al. (1986) Growthinhibitory effects of epidermal growth factor and overexpression of its receptors on human squamous cell carcinomas in culture. Cancer Res 46: 1648-1653.

140. Minke JMHM, Schuuring ED, van den Berghe R (1991) Isolation of two distinct epithelial cell lines from a single feline mammary carcinoma with differen tumorigenic potential in nude mice and expressing different levels of epidermal growth factor receptor. Cancer Res 51: 4028-4031.

141. Lee JC, Vivanco I, Beroukhim R, Huang JH, Feng WL, et al. (2006) Epidermal growth factor receptor activation in glioblastoma through novel misdense mutations in extracellular domain. PLoS medicine 3: e485.

142. Miltra S, Han S, Soderstram K, Wong A (2012) Preferential expression of an oncogenic receptor in brain tumor stem cells: Identification and targeting using an engineered antibody. In: Proc Am Assoc Cancer Res. Cancer Res p: 72

143. Hembrough T, Thyparambil S, Liao WL, Darfler M, Krizman D, et al. (2012) Quantitative multiplexed SRM analysis of oncogenic receptors in FFPE colorectal carcinoma tissue. AACR 103rd Annual Meeting Chicago, IL. Cancer Res 72:5537.

144. Godin-Heymann N, Bryant I, Rivera MN, Ulkus L, Bell DW, et al. (2007) Oncogenic activity of epidermal growth factor receptor kinase mutant alleles is enhanced by the T790M drug resistance mutation. Cancer Res 67: 7319-7326. [Crossref] 
145. Rosell R, Molina MA, Costa C, Simonetti S, Gimenez-Capitan A, et al. (2011) Pretreatment EGFR T790M mutation and BRCA1 mRNA expression in erlotinibtreated advanced non-small-cell lung cancer patients with EGFR mutations. Clin Cancer Res 17: 1160-1168. [Crossref]

146. Karachaliou N, Gimenez-Capitan A, Drozdowskyj A, Viteri S, Moran T, et al. (2014) ROR1 as a novel therapeutic target for EGFR-mutant non-small-cell lung cancer patients with the EGFR T790M mutation. Transl Lung Cancer Res 3: 122-130. [Crossref]

147. Gallant JN, Sheehan JH (2015) EGFR kinase domain duplication(EGFR-KDD) is a novel oncogenic driver in lung cancer that is clinically responsive to afatinib. Cancer Discov 5: 1155-1163.

148. Konduri K, Gallant JN, Chae YK, Giles FJ, Gitlitz BJ, et al. (2016) EGFR Fusions as Novel Therapeutic Targets in Lung Cancer. Cancer Discov 6: 601-611. [Crossref]

149. Ichihara E, Takeda H, Kubo T, Hirano S, Yoshino T, et al. (2009) Chemopreventive effect of gefitinib on nonsmoking-related lung tumorigenesis in activating epidermal growth factor receptor transgenic mice. Cancer Res 69:7088-95.

150. Blesa JM1, Mollá SB, Esparcia MF, Ortells JM, Godoy MP, et al. (2012) Durable complete remission of a brainstem glioma treated with a combination of bevacizumab and cetuximab. Case Rep Oncol 5: 676-681. [Crossref]

151. Rodríguez PC, Rodríguez G, González G, Lage A (2010) Clinical development and perspectives of CIMAvax EGF, Cuban vaccine for non-small-cell lung cancer therapy. MEDICC Rev 12: 17-23. [Crossref]

152. Gonzalez G, Crombet T, Lage A (2011) Chronic vaccination with a therapeutic EGFbased cancer vaccine: a review of patients receiving long lasting treatment. Curr Cancer Drug Targets 11: 103-110. [Crossref]

153. Paugh BS, Zhu X, Qu C, Endersby R, Diaz AK, et al. (2013) Novel oncogenic PDGFRA mutations in pediatric high-grade gliomas. Cancer Res 73: 6219-6229.

154. Yamada Y, Rothenberg ME, Lee AW, Akei HS, Brandt EB, et al. (2006) The FIPIL1PDGFRA fusion gene cooperates with IL-5 to induce murine hyper-eosinophilic syndrome (HES)/chronic eosinophilic leukemia(CEL)-like disease. Blood 107: 407179 .

155. Golub TR, Barker GF, Lovett M, Gilliland DG (1994) Fusion of PDGF receptor beta to a novel ets-like gene, tel, in chronic myelomonocytic leukemia with $t(5 ; 12)$ chromosomal translocation. Cell 77: 307-316. [Crossref]

156. M, Ueda I, Matsumura I, Ishiko J, Schwble J, et al. (2003) Oncogenic receptor tyrosine kinase in leukemia. Cell Mol Biol (Noisy-le-grand) 49: 907-922. [Crossref]

157. Matsumura I, Mizuki M, Kanakura Y (2008) Roles for deregulated receptor tyrosine kinase and their downstream signaling molecules in hematologic malignancies. Cancer Science 99: 479-85.

158. Lierman E, Lahortiga I, Miegroet HV, Mentes N, Maryneri P, et al. (2007) The ability of sorafenib to inhibit oncogenic PDGFRbeta and FLT3 mutants and overcome resistance to other small molecular inhibitors. Haematologica 92: 27-34.

159. Holzmann K, Grunt T, Heinzle C, Sampl S, Steinhoff H, et al. (2012) Alternative splicing of fibroblast growth factor receptor IgIII loops in cancer. J Nucleic Acids 15 : 950508 .

160. Mcgee GS (1988) Recombinant basic fibroblast growth factor acclerate wound healing. J Surg Res 45: 145.

161. Oda Y, Kagami H, Ueda M (2004) Acclerating effects of basic growth factor on wound healing of rat platal mucosa. J Oral Maxillofac Surg 62: 73-80.

162. Apperley JF, Gardenbas M, Melo JV (2002) Response to imatinib mesylate in patients with chronic myeloproliferative disorders with rearrangements of platelet-derived growth factor receptor beta. $N$ Engl J Med 347: 481-487.

163. Cools J, DeAngelo DJ, Gotlib J (2003) A tyrosine kinase created by fusion of the PDGFRA and FIPIL1 gene as a therapeutic target of imatinib in idiopathic hypereosinophilic syndrome. $N$ Engl J Med 348:1201-1214

164. Klion AD (2007) Relapse following discontinuation of imatinib mesylate therapy for FIPIL1/ PDGFRA-positive chronic eosinophilic leukemia: implications for optimal dosing. Blood 110: 3552-3356.

165. Jovanovic JV, Score J (2007) Low-dose imatinib mesylate leads to rapid molecular responses and achievement of complete molecular remission in FIPIL1-PDGFRApositive chronic eosinophilic leukemia. Blood 109: 4635-4640.

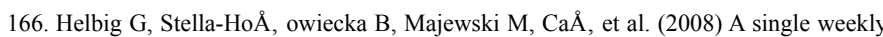
dose of imatinib is sufficient to induce and maintain remission of chronic eosinophilic leukaemia in FIP1L1-PDGFRA-expressing patients. Br J Haematol 141: 200-204.
[Crossref]

167. Arefi M, García JL, Briz MM, de Arriba F, Rodríguez JN, et al. (2012) Response to imatinib mesylate in patients with hypereosinophilic syndrome. Int J Hematol 96 : 320-326. [Crossref]

168. Kuroiwa M, Hiwatari M, Hirato J, Suzuki N, Tsuchida Y, et al. (2005) Advancedstage gastrointestinal tumor treated with imatinib in a 12-year-old girl with a unique mutation of PDGFRA. J Pediatr Surg 40: 1798-801

169. MacDougall CA, Vargas M, Soares CR, Holzer RG, Ide AE, et al. (2005) Involvement of HGF/SF-Met signaling in prostate adenocarcinoma cells: evidence for alternative mechanisms leading to a metastatic phenotype in Pr-14c. Prostate 64: 139-148. [Crossref]

170. Spee B, Arends B, van den Ingh TS, Roskams T, Rothuizen J, et al. (2007) Major HGF-mediated regenerative pathways are similarly affected in human and canine cirrhosis. Comp Hepatol 6: 8. [Crossref]

171. Fieten H, Spee B, Ijzer J, Kik MJL, Penning LC, et al. (2009) Expression of hepatocyte growth factor and the proto-oncogenic receptor c-Met in canine osteosarcoma. Veterinary Pathology 46: 869-877.

172. Nakamura T, Sakai K, Nakamura T, Matsumoto K (2011) Hepatocyte growth factor twenty years on: Much more than a growth factor. J Gastroenterol Hepatol 26 Suppl 1: 188-202. [Crossref]

173. Ishiki Y, Ohnishi H, Muto Y, Matsumoto K, Nakamura T (1992) Direct evidence that hepatocyte growth factor is a hepatotrophic factor for liver regeneration and has a potent antihepatitis effect in vivo. Hepatology 16: 1227-1235. [Crossref]

174. Matsuda Y, Matsumoto K, Ichida T, Nakamura T (1995) Hepatocyte growth facto suppresses the onset of liver cirrhosis and abrogates lethal hepatic dysfunction in rats. J. Biochem 118: 643-649.

175. Jeffers M, Rong S, Anver M, Vande Woude GF (1996) Autocrine hepatocyte growth factor/scatter factor-Met signaling induces transformation and the invasive/metastatic phenotype in C127 cells. Oncogene 13: 853-856.

176. Olwill SA, Joffroy C, Gille H, Vigna E, Matschiner G, et al. (2013) A highly potent and specific MET therapeutic protein antagonist with both ligand-dependent and ligand-independent activity. Mol Cancer Ther 12: 2459-2471.

177. Goyal L, Muzumdar MD, Zhu AX (2013) Targeting the HGF/c-MET pathway in hepatocellular carcinoma. Clin Cancer Res 19: 2310-2318. [Crossref]

178. Kentsis A, Reed C, Rice KL, Sanda T, Rodig SJ, et al. (2012) Autocrine activation of the MET receptor tyrosine kinase in acute myeloid leukemia. Nat Med 18: 1118-1122. [Crossref]

179. Kanda H, Tajima H, Lee GH, Nomura K, Ohtake K, et al. (1993) Hepatocyte growth factor transforms immortalized mouse liver epithelial cells. Oncogene 8: 3047-3053. [Crossref]

180. Shiota G, Rhoads DB, Wang TC, Nakamura T, Schmidt EV (1992) Hepatocyte growth factor inhibits growth of hepatocellular carcinoma cells. Proc Natl Acad Sci USA 89: 373-377.

181. Gentile A, Trusolino L, Comoglio PM (2008) The Met tyrosine kinase receptor in development and cancer. Cancer Metastasis Rev 27: 85-94. [Crossref]

182. Medová M, Pochon B, Streit B, Blank-Liss W, Francica P, et al (2013) The novel ATPcompetitive inhibitor of the MET hepatocyte growth factor receptor EMD1214063 displays inhibitory activity against selected MET-mutated variants. Mol Cancer Ther 12: $2415-2424$

83. Gual P, Giordano S, Anguissola S, Parker PJ, Comoglio PM (2001) Gab phosphorylation: a novel mechanism for negative regulation of HGF receptor signaling. Oncogene 20: 156-166. [Crossref]

184. Vigna E, Pacchiana G, Chiriaco C, Cignetto S, Fontani L, et al. (2014) Targeted therapy by gene transfer of a monovalent antibody fragment against the Met oncogenic receptor. J Mol Med (Berl) 92: 65-76. [Crossref]

185. Vigna E, Chiriaco C, Cignetto S, Fontani L, Basillico C, et al. (2015) Inhibition of ligand-independent constitutive activation of the Met oncogenic receptor by the engineered chemically -modified antibody DN30. Mol Oncol pil: S1574.

186. Lobie PE (2005) The oncogenic potential of autocrine human growth hormone in breast cancer. Twelfth International Congress of Endocrinology, Lisbon.

187. Zhu T, Starling Emeral B, Zhang X, Lee KO, Gluckman PO, et al. (2005) Oncogenic transformation of human mammary epithelial cells by autocrine human growth hormone. Cancer Res. 
188. Conway-Campbell BL, Wooh JW, Brooks AJ, Gordon D, Brown RJ, et al. (2007) Nuclear targeting of the growth hormone receptor results in dysregulation of cell proliferation and tumorigenesis. Proc Natl Acad Sci U S A 104: 13331-13336. [Crossref]

189. Lincoln DT, Kaiser HE, Raju GP, Waters MJ (2000) Growth hormone and colorectal carcinoma: localization of receptors. In Vivo 14: 41-49. [Crossref]

190. Yash C, Waters MJ, Brooks A (2014) The growth hormone receptor mediated oncogenesis. Institute for Molecular Bioscience, The University of Queensland.

191. Rosenbloom AL, Guevara-Aguirre J, Rosenfeld RG, Francke U (1999) Growth hormone receptor deficiency in Ecuador. J Clin Endocrinol Metab 84: 4436-4443. [Crossref]

192. Palmiter RD, Brinster RL, Hammer RE, Trambauer ME, Rosenfeld MG, et al. (1982) Dramatic growth of mice that develop from eggs microinjected with metallothioneingrowth hormone fusion genes. Nature 300: 611-615.

193. Orian JM, Tamkoshi K, Mackmy LR, Brandon MR (1990) New murine model for hepatocellular carcinoma, transgenic mice expressing metallothionein-ovine growth hormone fusion gene. J Natl Cancer Inst 82: 393-398.

194. Orme SM, McNally RJ, Cartwright RA, Belchetz PE (1998) Mortality and cancer incidence in acromegaly: a retrospective cohort study. J Clin Endocrinol Metab 83: 2730-2734.

195. Beuschiein F (2000) Acromegaly caused by secretion of growth hormone by a nonHodgkin's lymphoma. N Engl J Med 342: 1871-1876.

196. Törnell J, Rymo L, Isaksson OG (1991) Induction of mammary adenocarcinomas in metallothionein promoter-human growth hormone transgenic mice. Int J Cancer 49 : 114-117. [Crossref]

197. Jenkins PJ (2006) Cancers associated with acromegaly. Neuroendocrinology 83: 218223. [Crossref]

198. Mayo KE, Hammer RE, Swanson LW, Brinster RL, Rosenfeld MG, et al. (1988) Dramatic pituitary hyperplasia in transgenic mice expressing a human growth hormone-releasing factor gene. Mol Endocrinol 2: 606-612. [Crossref]

199. Asa SL, Kovacs K, Stefaneanu L, Horvath E, Billestrup N, et al. (1992) Pituitary adenomas in mice transgenic for growth hormone-releasing hormone. Endocrinology 131: 2083-2089. [Crossref]

200. Wang LH, Lin B, Jong SM, Dixon D, Ellis L, et al. (1987) Activation of transforming potential of the human insulin receptor gene. Proc Natl Acad Sci USA 84: 5725-5729.

201. Zong CS, Zeng L, Jiang Y, Sadowski HB, Wang LH (1998) Stat3 plays an importan role in oncogenic ROS- and insulin-like growth factor I receptor-induced anchorageindependent growth. J Bio Chem 273: 28065-28072.

202. Kaleko M, Rutter WJ, Miller AD (1990) Overexpression of the human insulin like growth factor-1 receptor promotes ligand-dependent neoplastic transformation. $\mathrm{Mol}$ Cell Biol 10: 464-473.

203. Giorgino F, Belfiore A, Milazzo G, Costantino A, Maddux B, et al. (1991) Overexpression of insulin receptors in fibroblast and ovary cells induces a ligandmediated transformed phenotype. Mol Endocrinol 5: 452-459. [Crossref]

204. Karrman $\mathrm{K}$ (2009) The $\mathrm{t}(\mathrm{X} ; 7)(\mathrm{q} 22 ; \mathrm{q} 34)$ in paediatric T-cell acute lymphoblastic leukemia results in overexpression of the insulin receptor substrate 4 gene through illegitimate recombination with the T-cell receptor beta locus. Br J Haematol 144: 546-551.

205. Hankinson SE (1998) Circulating concentrations of IGF-1 and risk of breast cancer. Lancet 351:1391-1396.

206. Jones RA, Campbell CI, Gunther EJ, Chodosh LA, Khokha R, et al. (2007) Transgenic overexpression of IGF-1R disrupts mammary ductal morphogenesis and induces tumor formation. Oncogene 26: 1636-1644.

207. Carboni JM (2005) Tumor development by transgenic expression of a constitutively active insulin-like growth factor I receptor. Cancer Res 65: 3181-3187.

208. Pisani P (2008) Hyper-insulinaemia and cancer, meta-analyses of epidemiological studies. Arch Physiol Biochem 114: 63-70. [Crossref]

209. Klinger B, Laron Z (1995) Three year IGF-I treatment of children with Laron syndrome. J Pediatr Endocrinol Metab 8: 149-158. [Crossref]

210. Rosenbloom AL1 (2009) Mecasermin (recombinant human insulin-like growth factor I). Adv Ther 26: 40-54. [Crossref]

211. Ranke MB, Savage MO, Chatelain PG, Preece MA, Rosenfeld RG, et al. (1999) Long- term treatment of growth hormone insensitivity syndrome with IGF-I. Results of the European Multicentre Study. The Working Group on Growth Hormone Insensitivity Syndromes. Horm Res 51: 128-134. [Crossref]

212. McKinsey EL, Parrish JK, Irwin AE, Niemeyer BF, Kern HB, et al. (2011) A nove oncogenic mechanism in Ewing sarcoma involving IGF pathway targeting by EWS/ Fli1-regulated microRNAs. Oncogene 30: 4910-4920. [Crossref]

213. Naing A, LoRusso P, Fu S, Hong DS, Anderson P, et al. (2012) Insulin growth factor-receptor(IGF-1R) antibody cixutumumab combined with the mTOR inhibitor temsirolimus in patients with refractory Ewing's sarcoma family tumors. Clin Cancer Res 18: 2625-2631.

214. Tap WD, Demetri G, Barnette P, Desai J, Kavan P, et al. (2012) Phase II study of ganitumab, a fully human anti-type-1 insulin-like growth factor receptor antibody, in patients with metastatic Ewing family tumors or desmoplastic small round cell tumors. J Clin Oncol 30: 1849-1856. [Crossref]

215. Sommer A, Kopitz C, Schatz CA, Nising CF, Mahlert C, et al. (2016) Preclinica efficacy of the auristatin-based antibody-drug conjugate BAY 1187982 for the treatment of FGFR2-positive solid tumors. Cancer Res. [Crossref]

216. Kostman R (1975) Infantile genetic agranulocytosis. A review with presentation of ten new cases. Acta Paediatr Scand 64: 362-368. [Crossref]

217. Dale DC, Bonilla MA, Davis MW, Nakanishi AM, Hammond WP, Kurtzberg J, et al. (1993) A randomized controlled phase III trial of recombinant human granulocyte colony stimulating factor (filgrastim) for treatment of severe chronic neutropenia Blood 81: 2496.

218. Hubel K, Dale DC, Liles WC (2002) Therapeutic use of cytokines to modulate phagocytic function for the treatment of infectious diseases: current status of G-CSF, GM-CSF, M-CSF, andIFN-r. J Infect Dis 185: 1490-1501.

219. Zeidler C, Boxer L, Dale DC, Freedman MH, Kinsey S, et al. (2000) Managemen of Kostmann syndrome in the G-CSF era. Br J Haematol 109: 490-495. [Crossref]

220. Donini M (2007) G-CSF treatment of severe congenital neutropenia reverses neutropenia but does not correct the underlying functional deficiency of the neutrophil in defending against microorganisms. Blood 109: 4716.

221. Rosenberg PS, Zeidler C, Bolyard AA, Alter BP, Bonilla MA, et al. (2010) Stable long-term risk of leukaemia in patients with severe congenital neutropenia maintained on G-CSF therapy. Br J Haematol 150: 196-199. [Crossref]

222. Beekman R and Touw IP (2010) G-CSF and its receptor in myeloid malignancy. Blood 115: 5131-5136.

223. Hunter MG, Avalos BR (2000) Granulocyte colony-stimulating factor recepto mutations in severe congenital neutropenia transforming to acute myelogenous leukemia confer resistance to apoptosis and enhance cell survival. Blood 95: 2132.

224. Germeshausen M, Ballmaier M, Welte K (2007) Incidence of CSF3R mutations in severe congenital neutropenia and relevance for leukemogenesis: Results of a longterm survey. Blood 109: 93-99. [Crossref]

225. Beel K, Vandenberghe P (2009) G-CSF receptor (CSF3R) mutations in X-linked neutropenia evolving to acute myeloid leukemia or myelodysplasia. Haematologica 94: 1449-1452. [Crossref]

226. Fleischman AG, Maxson JE, Luty SB, Agarwal A, Royer LR, et al. (2013) The CSF3R T618I mutation causes a lethal neutrophilic neoplasia in mice that is responsive to therapeutic JAK inhibition. Blood 122: 3628-3631. [Crossref]

227. Maxson JE, Gotlib J, Pollyea DA, Fleischman AG, Agarwal A, et al. (2013) Oncogenic CSF3R mutations in chronic neutrophilic leukemia and atypical CML. $N$ Engl J Med 368: 1781-1790. [Crossref]

228. Plo I, Zhang Y, Le Couédic JP, Nakatake M, Boulet JM, et al. (2009) An activating mutation in the CSF3R gene induces a hereditary chronic neutrophilia. J Exp Med 206 : 1701-1707. [Crossref]

229. Russell LJ, De Castro DG, Griffiths M, Telford N, Bernard O, et al. (2009) A novel translocation, $\mathrm{t}(14 ; 19)(\mathrm{q} 32 ; \mathrm{p} 13)$, involving IGH@ and the cytokine receptor for erythropoietin. Leukemia 23: 614-617. [Crossref]

230. Iacobucci I (2014) Cryptic truncating rearrangement of the erythropoietin receptor in ph-like acute lymphoblastic leukemia. Blood 124:128.

231. Iacobucci I (2016) Truncating erythropoietin receptor rearrangements in acute lymphoblastic leukemia. Cancer Cell 29: 186-200.

232. Longmore GD, Pharr P, Neumann D, Lodisb HF (1993) Both megakaryocytopoiesis and erythropoiesis are induced in mice infected with a retrovirus expressing an oncogenic erythropoietin receptor. Blood 82: 2386-2395. 
233. De la Chapelle A (1993) Truncated erythropoietin receptor cause dominantly inherited benign human erythrocytosis. Proc Natl Acad Sci USA 90: 4495-4499.

234. Arcasoy MO, Karayal AF, Segal HM, Sinning JG, Forget BG (2002) A novel mutation in the erythropoietin receptor gene is associated with familial erythrocytosis. Blood 99: 3066-3069. [Crossref]

235. Forget BG, Degan BA, Arcasoy MO (2000) Familial polycythemia due to truncations of the erythropoietin receptor. Trans Am Clin Climatol Assoc 111: 38-44. [Crossref]

236. Perrotta S, Cucciolla V, Ferraro M, Ronzoni L, Tramontano A, et al. (2010) EPO receptor gain-of-function causes hereditary polycythemia, alters CD34 cell differentiation and increases circulating endothelial precursors. PLoS One 5: e12015. [Crossref]

237. Bento C (2013) Molecular study of congenital erythrocytosis in 70 unrelated patients revealed a potential causal mutation in less than half of the cases. Eur J Hematol 91: 361-368.

238. Maruyama M, Shibuya H, Harada H, Hatakeyama M, Seiki M, et al. (1987) Evidence for aberrant activation of the interleukin-2 autocrine loop by HTLV-1-encoded $\mathrm{p} 40 \mathrm{x}$ and T3/Ti complex triggering. Cell 48: 343-350. [Crossref]

239. Yamada G, Kitamura Y, Sonoda H, Harada H, Taki S, et al. (1987) Retroviral expression of the human IL-2 gene in a murine $\mathrm{T}$ cell line results in cell growth autonomy and tumorigenicity. EMBO J 6: 2705-2709. [Crossref]

240. Karasuyama H, Tohyama N, Tada T (1989) Autocrine growth and tumorigenicity of interleukin 2-dependent helper T cells transfected with IL-2 gene. J Exp Med 169: 13-25. [Crossref]

241. Nagarkatti M, Hassuneh M, Seth A, Manickasundari K, Nagarkatti PS (1994) Constitutive activation of the interleukin 2 gene in the induction of spontaneous in vitro transformation and tumorigenicity of T cells. Proc Natl Acad Sci U S A 91: 76387642. [Crossref]

242. Hassuneh MR, Nagarkatti PS, Nagarkatti M (1997) Evidence for the participation of interleukin-2 (IL-2) and IL-4 in the regulation of autonomous growth and tumorigenesis of transformed cells of lymphoid origin. Blood 89: 610-620. [Crossref]

243. Laâbi Y, Gras MP, Carbonnel F, Brouet JC, Berger R, et al. (1992) A new gene, $\mathrm{BCM}$, on chromosome 16 is fused to the interleukin 2 gene by a $\mathrm{t}(4 ; 16)(\mathrm{q} 26 ; \mathrm{p} 13)$ translocation in a malignant T cell lymphoma. EMBO J 11: 3897-3904. [Crossref]

244. Goldsmith MA (1995) Growth signal transduction by the human interleukin-2 receptor requires cytoplasmic tyrosines of the beta chain and non-tyrosine residues of the rc chain. J Biol Chem 270: 21729-21737.
245. Rosenberg SA (1985) Observation on the systemic administration of autologous lymphokine- activated killer cells and recombinant interleukin-2 to patients with metastatic cancer. $N$ Engl J Med 313: 1485.

246. Bernard O, Ullrich A (1987) High-affinity interleukin 2 binding by an oncogenic hybrid interleukin 2-epidermal growth factor receptor molecule. PNAS 84:2125-2129.

247. Pike-Overzet K, de Ridder D, Weerkamp F, Baert MR, Verstegen MM, et al. (2006) Gene therapy: is IL2RG oncogenic in T-cell development. Nature 443: E5. [Crossref]

248. Grimaldi JC, Meeker TC (1989) The $\mathrm{t}(5 ; 14)$ chromosomal translocation in a case of acute lymphocytic leukemia joins the interleukin-3 gene to the immunoglobulin heavy chain gene. Blood 73: 2081-2085.

249. Steelman LS, Algate PA, Blalock WL, Wang XY, Prevost KD, et al. (1996) Oncogenic effects of overexpression of the interleukin-3 receptor on hematopoietic cells. Leukemia 10: 528-542. [Crossref]

250. Durum SK1 (2014) IL-7 and TSLP receptors: twisted sisters. Blood 124: 4-5 [Crossref]

251. Sasson SC, Zaunders JJ, Kelleher AD (2006) The IL-7/IL-7 receptor axis: understanding its central role in T-cell homeostasis and the challenges facing its utilization as a novel therapy. Curr Drug Targets 7: 1571-1582. [Crossref]

252. Shochat C, Tal N, Gryshkova V, Birger Y, Bandapalli OR, et al. (2014) Novel activating mutations lacking cysteine in type I cytokine receptors in acute lymphoblastic leukemia. Blood 124: 106-110. [Crossref]

253. Mansour MM (2013) Targeting oncogenic interleukin-7 receptor signaling. Blood 122 2535 .

254. Ueda C, Akasaka T, Kurata M, Maesako Y, Nishikori M, et al. (2002) The gene for interleukin-21 receptor is the partner of $\mathrm{BCL}$ in $\mathrm{t}(3 ; 16)(\mathrm{q} 27 ; \mathrm{p} 11)$, which is recurrently observed in diffuse large B-cell lymphoma. Oncogene 21: 368-376.

255. Moody P, Sayers EJ, Magnusson JP, Alexander C, Borri P, et al. (2015) Receptor crosslinking: A general method to trigger internalization and lysosomal targeting of therapeutic receptor: ligand complexes. Molecular Therapy 23: 1888-1898.

256. Kirschning CJ, Dreher S, Maass B, Fichte S, Schade J, et al. (2010) Generation of anti-TLR2 interbody mediating inhibition of macrophage surface TLR2 expression and TLR2-driven cell activation. BMC Biotechnol 10: 31. [Crossref]

257. Ornes S (2013) Antibody-drug conjugates. Proc Natl Acad Sci U S A 110: 13695. [Crossref]

258. Zhao Y (2016) The oncogenic functions of nicotinic acetylcholine receptors. Journal of Oncology 3:1-9.

Copyright: (C)2016 Zhu G. This is an open-access article distributed under the terms of the Creative Commons Attribution License, which permits unrestricted use, distribution, and reproduction in any medium, provided the original author and source are credited. 